\title{
THE IMPORTANCE OF CLAVICLE ANGLE AND HEIGHT OF THE CORACOID PROCESS IN IDIOPATHIC SCOLIOSIS
}

\author{
IMPORTÂNCIA DO ÂNGULO CLAVICULAR E ALTURA DO CORACOIDE NA ESCOLIOSE \\ IDIOPÁTICA
}

\section{LA IMPORTANCIA DEL ÁNGULO CLAVICULAR Y DE LA ALTURA DEL PROCESO CORACOIDE EN ESCOLIOSIS IDIOPÁTICA}

\author{
Cristiano Magalhães Menezes, ${ }^{1}$ Rodrigo Souza Lima, ${ }^{1}$ Roberto Sakamoto Falcon, ${ }^{1}$ Reinaldo Elias de Souza Junior ${ }^{2}$ \\ 1. Hospital Ortopédico / Lifecenter, Spine Surgery, Belo Horizonte, MG, Brazil. \\ 2. Universidade Federal Goiás, Acadêmico Medicina, Goiânia, GO, Brazil.
}

\begin{abstract}
Objective: The aim of this study was to correlate the parameters of shoulder alignment with the Cobb angle value of the proximal thoracic curve in the pre and postoperative periods. Methods: A retrospective data collection study was carried out, in which 30 medical records and radiographic examinations of patients submitted to surgical treatment for correction of deformity in AIS were performed in a single center from 2010 to 2017. Results: The risk of CHD> $3 \mathrm{~mm}$ at 1 year postoperatively was similar between patients who had high thoracic curve (HTC) less than or equal to 25 degrees and those who had HTC greater than 25 degrees and not structured (relative risk $=1.75$, P-value $=0.552$ ). The risk of presenting CA> 2 degrees in the postoperative period of 1 year was similar between patients having HTC less than or equal to 25 degrees and those who had HTC greater than 25 degrees and not structured (relative risk $=1.31$, P-value $=0.567$ ). Conclusions: We observed that when the proximal thoracic curve is not structured, even with a high Cobb angle, there is no need for instrumentation, presenting a satisfactory shoulder alignment in the postoperative period. Level of Evidence III; Retrospective and Comparative.
\end{abstract}

Keywords: Scoliosis; Pathogenesis; Research/Etiology.

\section{RESUMO}

Objetivo: O objetivo deste estudo é correlacionar os parâmetros do alinhamento do ombro com o valor de ângulo Cobb da curva torácica proximal no pré e pós-operatório. Métodos: Foi realizado um estudo com base em coleta de dados retrospectivos, em que foram avaliados 30 prontuários e exames radiográficos de pacientes submetidos ao tratamento cirúrgico para a correção da deformidade na EIA em um único centro, no período de 2010 a 2017. Resultados: O risco de apresentar CHD >3mm no pós-operatório de 1 ano foi semelhante entre os pacientes que apresentavam CTA menor ou igual a 25 graus e naqueles em que esta era maior que 25 graus e não estruturadas. (Risco relativo=1.75, $P$-valor=0.552). O risco de apresentar CA>2 graus no pós-operatório de 1 ano foi semelhante entre os pacientes que apresentavam curva torácica alta (CTA) menor ou igual a 25 graus e naqueles em que esta era maior que 25 graus e não estruturadas (Risco relativo=1.31, $P$-valor=0.567). Conclusão: Obsenvamos que quando a curva torácica proximal não é estruturada, mesmo com elevado valor de ângulo Cobb, não há necessidade de instrumentação, apresentando um satisfatório alinhamento dos ombros no pós-operatório. Nível de Evidência III; Retrospectivo e Comparativo.

Descritores: Escoliose; Patogênese; Pesquisa/Etiologia.

\section{RESUMEN}

Objetivo: El objetivo de este estudio fue correlacionar los parámetros de alineación del hombro con el valor de ángulo de Cobb de la curva torácica proximal en los periodos pre y postoperatorio. Métodos: Se realizó un estudio retrospectivo de recolección de datos, en el que se evaluaron 30 registros médicos y exámenes radiográficos de pacientes sometidos al tratamiento quirúrgico para la corrección de la deformidad en EIA en un solo centro desde 2010 hasta 2017. Resultados: El riesgo de CHD $>3 \mathrm{~mm}$ a 1 año de postoperatorio fue similar entre los pacientes que tenían curva torácica alta (CTA) menor o igual a 25 grados y los que tenían CTA mayor que 25 grados y no estructuradas (riesgo relativo $=1,75, P=0,552$ ). El riesgo de presentar $C A>2$ grados en el postoperatorio de 1 año fue similar entre los pacientes que presentaban CTA menor o igual a 25 grados y en los con CTA mayor que 25 grados y no estructuradas (riesgo relativo $=1,31, P=0,567$ ). Conclusiones: Observamos que cuando la curva torácica proximal no está estructurada, incluso con ángulo de Cobb grande, no es necesaria la instrumentación, y hay alineación satisfactoria del hombro en el postoperatorio. Nivel de Evidencia III; Retrospectivo y Comparativo.

Descriptores: Escoliosis; Patogénesis; Investigación/Etiología.

\section{INTRODUCTION}

Good results from surgical treatment of adolescent idiopathic scoliosis (AIS) are often attributed to adequate correction of the structured curves in the three planes: axial, coronal, and sagittal.
However, other factors, such as shoulder height and the correction of gibbosity, perform an important role in the positive assessment of the treatment implemented. Such factors influence not only the perception of a good surgical result, but also the patients' satisfaction with 
the therapy and their psychological well-being after the procedure. ${ }^{1}$

The double thoracic curve in adolescent idiopathic scoliosis (AIS) is a well-known deformity. In this sense, the shoulder alignment is an important component that must be considered in these deformities, ${ }^{2}$ since the left shoulder is frequently lower than the right shoulder. In fact, the characteristic of the proximal thoracic curves needs to be correlated with these alterations in an effort to obtain a good surgical outcome. ${ }^{3}$

One of the postoperative goals is to achieve satisfactory shoulder alignment. Initially, the surgeon must determine whether the proximal thoracic (PT) curve will require instrumentation. It is worth noting that some clinical and radiographic data assist in decision making, such as, for example, whether the left shoulder is more elevated, whether the transition of the PT curve to the main thoracic curve is below T5, or whether there is regional kyphosis greater than 25 degrees between T2 and T5. ${ }^{4}$

Earlier studies have demonstrated that preoperative evaluation of shoulder alignment using measurements from radiographic examinations, such as the clavicle angle (CA), the height of the coracoid process, and the alignment of the ribs, are predictive of a good postoperative outcome, but it is not yet clear to what point these factors are relevant in making a decision. ${ }^{5}$

Thus, the objective of this study is to correlate the shoulder alignment parameters with the Cobb angle of the proximal thoracic curve in both the pre- and postoperative periods.

\section{METHODS}

This study was based on retrospective data collection. After approval by the Institutional Review Board as number 81028517.0.0000.513 and the signing of the ICF, we evaluated the medical records and radiographical examinations of 30 patients who had undergone surgical treatment to correct AIS deformity in a single center during the period from 2010 to 2017.

From this point, patients between 10 and 18 years of age diagnosed with AIS and classified as Lenke types 1, 3, 5, or 6 were included. All the cases with structured proximal thoracic curves of Lenke types 2 and 4 , as well as those patients with non-idiopathic scoliotic deformities or less than 1 year of follow-up were excluded from the study.

It should be noted that the radiographical evaluation was conducted by means of the following parameters: difference in the height of the coracoid process (CHD), clavicle angle (CA), pelvic incidence $(\mathrm{PI})$, pelvic version (PV), sacral inclination (SI), lumbar lordosis (LL), primary thoracic kyphosis (TK) T5-T12, and Cobb angles of the proximal thoracic, primary thoracic, and thoracolumbar/lumbar curves.

The measurement of the coracoid process height difference $(\mathrm{CHD})$ was calculated as the difference in height in millimeters between the horizontal lines passing through the upper margin of each coracoid process. The value of the clavicle angle (CA) was obtained between the line that passes through the highest point of the clavicle and the horizontal plane. (Figure 1)

After measuring these parameters, the patients were divided into two groups according to the non-structured proximal thoracic curve. The first group included patients who had an HTC less than or equal to 25 degrees. The second group included patients with a

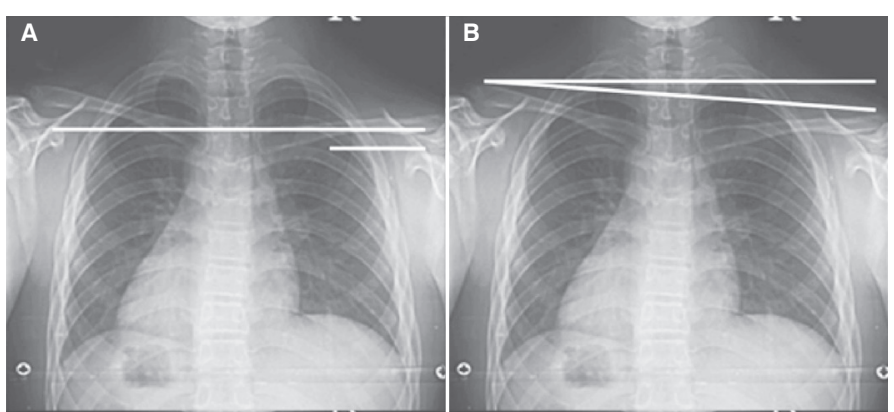

Figure 1. A: CHD B: CA. non-structured HTC greater than 25 degrees, that is, those whose lateral tilt radiographs had values less than 25 degrees, as recommended in Lenke's classification. These two groups were correlated with the shoulder leveling parameters.

Finally, the measurements were taken by the same examiner who had observed the preoperative radiographs and those taken after one year of follow-up using Surgimap Spine software (Nemaris Inc., New York, NY).

\section{Statistical analysis}

The Shapiro-Wilk Wilcoxon test was used to verify normal distribution of the variables lumbar lordosis and pelvic incidence.

Two contingency tables were constructed, considering the value of the high thoracic curve as the exposure variable and the values of the coracoid process height and the clavicle angle at 1 year following surgery, separately as outcome variables. The relative risks were calculated from these tables. A significance level of $95 \%$ was considered for all statistical tests used and Fisher's exact test was used to verify statistical significance.

\section{RESULTS}

It is relevant to point out at the outset that 30 patients with a mean age of 15.23 years were evaluated (Figure 2), of whom $80 \%$ were female and $20 \%$ male.

As regards the Lenke classification, 34\% of the patients were type $1,23 \%$ type $3,17 \%$ type 5 , and $26 \%$ were type 6 , with a mean preoperative high thoracic curve of 23.3 degrees ( 7 to 36 degrees). Therefore, in 14 of these patients the high thoracic curve was less than or equal to 25 degrees and in the remaining 16 patients it was greater than 25 degrees. As all the curves were compensatory, none were included in the surgical instrumentation.

That is, in the preoperative examinations the mean difference in coracoid process height (CHD) was $1.42 \mathrm{~mm}$ in patients with an HTC less than or equal to 25 degrees and $6.75 \mathrm{~mm}$ in patients with an unstructured HTC greater than 25 degrees. (Table 1)

Thus, we observed that, in the preoperative evaluation of the clavicle angle (CA), the mean clavicle angle was 1.71 degrees in the patients with an HTC less than or equal to 25 degrees and 4.36 degrees in those where it was greater than 25 degrees and non-structured. (Table 2)

In fact, in the preoperative period the mean corticoid process height difference was $1.17 \mathrm{~mm}$ in patients with a high thoracic curve greater than or equal to 25 degrees and $1.68 \mathrm{~mm}$ in those where it was greater than 25 degrees and non-structured. (Table 3)

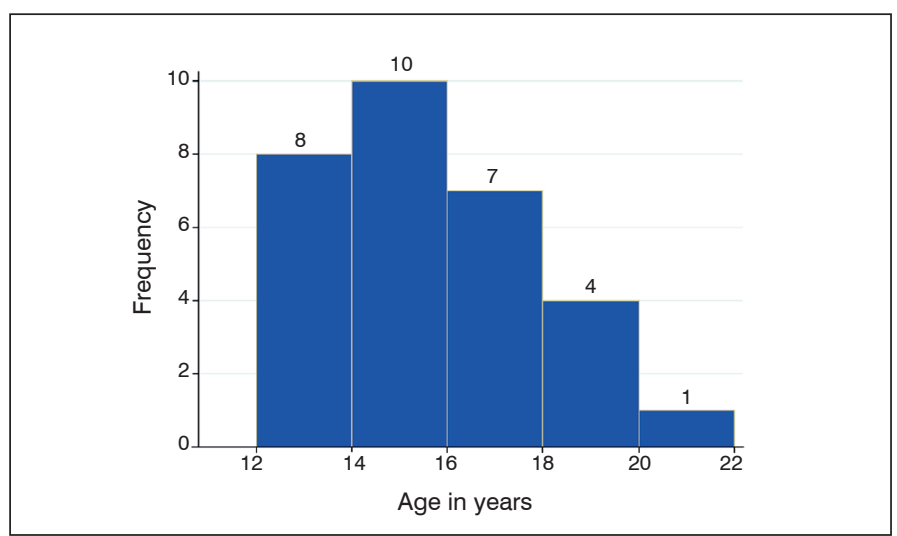

Figure 2. Distribution of the participants according to age.

Table 1. Mean difference in coracoid process height in relation to structured and non-structured proximal thoracic curves in the preoperative period.

\begin{tabular}{c|c|c|c|c|c}
\hline & & & $\mathbf{N}$ & Mean & Standard deviation \\
\hline \multirow{2}{*}{ CHD } & \multirow{2}{*}{ Pre-operative } & HTC $\leq 25$ & 14 & 1.42 & 0.93 \\
\cline { 3 - 6 } & & $H T C>25$ & 16 & 6.75 & 1.25 \\
\hline
\end{tabular}


After 1 year of follow-up, the mean difference in coracoid height was 1 degree in the patients whose high thoracic curve was less than or equal to 25 degrees and 1.2 degrees in those where the angle was greater than 25 degrees and non-structured. (Table 4)

The risk of presenting $\mathrm{CHD}>3 \mathrm{~mm}$ one year following surgery was similar among the patients with HTC less than or equal to 25 degrees and those where it was greater than 25 degrees and non-structured (relative risk $=1.75$, P-value $=0.552$ ). (Table 5)

The risk of presenting $\mathrm{CA}>2$ degrees one year following surgery was similar among the patients with HTC less than or equal to 25 degrees and those where it was greater than 25 degrees and non-structured (relative risk $=1.31, \mathrm{P}$-value $=0.567$ ). (Table 6)

It should be added that Tables 7 and 8 show the mean pre- and postoperative values of lumbar lordosis and pelvic incidence in the sagittal plane.

Table 7, included above, presents the summary measurements

Table 2. Mean clavicle angle in relation to the structured and non-structured proximal thoracic curves in the preoperative period.

\begin{tabular}{c|c|c|c|c|c}
\hline & & & $\mathbf{N}$ & Mean & Standard Deviation \\
\hline \multirow{2}{*}{$\mathrm{CA}$} & \multirow{2}{*}{ Preoperative } & $\mathrm{HTC} \leq 25$ & 14 & 1.71 & 0.91 \\
\cline { 3 - 6 } & & $\mathrm{HTC}>25$ & 16 & 4.36 & 1.09 \\
\hline
\end{tabular}

Table 3. Mean coracoid height difference in relation to the structured and non-structured proximal thoracic curves in the postoperative period.

\begin{tabular}{c|c|c|c|c|c}
\hline & & & $\mathbf{N}$ & Mean & Standard Deviation \\
\hline \multirow{2}{*}{$\mathrm{CHD}$} & \multirow{2}{*}{ Postoperative } & $\mathrm{HTC} \leq 25$ & 14 & 1.17 & 0.93 \\
\cline { 3 - 6 } & & $\mathrm{HTC}>25$ & 16 & 1.68 & 1.25 \\
\hline
\end{tabular}

Table 4. Mean clavicle angle in relation to the structured and non-structured proximal thoracic curves in the postoperative period.

\begin{tabular}{c|c|c|c|c|c}
\hline & & & $\mathbf{N}$ & Mean & Standard Deviation \\
\hline \multirow{2}{*}{$\mathrm{CA}$} & \multirow{2}{*}{ Postoperative } & $\mathrm{HTC} \leq 25$ & 14 & 1 & 0.91 \\
\cline { 3 - 6 } & & $\mathrm{HTC}>25$ & 16 & 1.2 & 1.09 \\
\hline
\end{tabular}

Table 5. Risk of presenting coracoid height difference greater than $3 \mathrm{~mm}$.

\begin{tabular}{l|c|c|c|c|c|c}
\hline & & $\begin{array}{c}\text { CHD } \\
\mathbf{3} \mathbf{3 m m}\end{array}$ & $\begin{array}{c}\text { CHD } \\
\mathbf{< 3 m m}\end{array}$ & Total & $\begin{array}{c}\text { Relative risk } \\
\text { (Cl 95\%) }\end{array}$ & P-value \\
\hline \multirow{2}{*}{$\mathrm{CHD}$} & $\mathrm{HTC} \leq 25$ & 1 & 13 & 14 & --- & --- \\
\cline { 2 - 8 } & $\mathrm{HTC}>25$ & 2 & 14 & 16 & $1.75(0.17-17.29)$ & 0.552 \\
\hline
\end{tabular}

Table 6. Risk of presenting clavicle angle greater than 2 degrees.

\begin{tabular}{c|c|c|c|c|c|c}
\hline & & CA $>\mathbf{2}$ ○ & CA $<\mathbf{2 0}$ & Total & $\begin{array}{c}\text { Relative risk (Cl } \\
\mathbf{9 5 \% )}\end{array}$ & P-value \\
\hline \multirow{2}{*}{$\mathrm{CA}$} & $\mathrm{HTC} \leq 25$ & 2 & 12 & 14 & --- & --- \\
\cline { 2 - 8 } & $\mathrm{HTC}>25$ & 3 & 13 & 16 & $1.31(0.25-6.76)$ & 0.567 \\
\hline
\end{tabular}

Table 7. Mean pre- and postoperative lumbar lordosis values.

\begin{tabular}{c|c|c|c|c|c|c|c}
\hline LL & n & Mean & $\begin{array}{c}\text { Standard } \\
\text { Deviation }\end{array}$ & Minimum & Maximum & $\begin{array}{c}\text { Shapiro- } \\
\text { Wilk test } \\
\text { (P-value) }\end{array}$ & $\begin{array}{c}\text { Paired } \\
\text { samples } \\
\text { Wilcoxon test } \\
\text { (P-value) }\end{array}$ \\
\hline pre-op & 30 & 54.03 & 15.27 & 14 & 78 & 0.329 & \multirow{2}{*}{0.399} \\
\hline post-op & 30 & 52.20 & 10.88 & 27 & 68 & 0.097 & \\
\hline
\end{tabular}

Table 8. Mean pre- and postoperative pelvic incidence.

\begin{tabular}{c|c|c|c|c|c|c|c}
\hline PI & $\mathbf{n}$ & Mean & $\begin{array}{c}\text { Standard } \\
\text { Deviation }\end{array}$ & Minimum & Maximum & $\begin{array}{c}\text { Shapiro- } \\
\text { Wilk test } \\
\text { (P-value) }\end{array}$ & $\begin{array}{c}\text { Paired } \\
\text { samples } \\
\text { Wilcoxon test } \\
\text { (P-value) }\end{array}$ \\
\hline pre-op & 30 & 53.41 & 11.28 & 34 & 79 & 0.490 & \multirow{2}{*}{0.474} \\
\hline post-op & 30 & 51.20 & 9.15 & 31 & 71 & 0.769 & \\
\hline
\end{tabular}

resulting from the paired sample Wilcoxon test for the variable lumbar lordosis in degrees.

Above, the summary measurements resulting from the normality test and the paired samples Wilcoxon test for the variable lumbar lordosis in degrees are shown.

From the above results, it was noted that in the postoperative examinations, the mismatch after 1 year was considered ideal $(+/-$ 09 degrees) in 29 patients (96.7\%). This did not occur in the case of 1 patient (3.3\%).

\section{DISCUSSION}

The treatment of idiopathic scoliosis has undergone considerable changes over the years due to advances in surgical procedures and techniques. Many factors contribute to patient satisfaction, such as for example, correction of the curve in the coronal plane and shoulder alignment. ${ }^{6}$

In this context, it is inferred that the evaluation of shoulder balance is one of the most important postoperative measurements for us to consider in determining whether a surgery was successful, 7,8 since several methods have been used to determine both pre- and postoperative shoulder balance. Indeed, the technological advances in radiographical imaging have made digitalization of radiographic data possible and, consequently, more precise evaluation that make the measurements more reliable. 9,10 $^{10}$

Hong et al., ${ }^{9}$ after conducting a study with 90 patients that compared 4 different techniques for measuring shoulder height, concluded that the CHD and CA methods are the most reliable. Terheyden et al. ${ }^{10}$ considered a $\mathrm{CHD}<4 \mathrm{~mm}$ and a $\mathrm{CA}<3^{\circ}$ to indicate good postoperative results.

From this point, our service follows a protocol of instrumentation for all structured proximal thoracic curves. Thus, the study by Lenke et al. with type 2 and 4 results, demonstrated that when proximal thoracic curves have a Cobb angle $>25^{\circ}$ in tilt radiographs they are considered to be structured curves and, as such, need to be included in the instrumentation. ${ }^{11}$

Thus, in the present study we evaluated the relationship of the non-structured high thoracic curve (HTC) to the unevenness of the shoulders. We observed that the greater the Cobb angle of the HTC, the greater the CHD and the CA would be. However, a year after surgical treated, we observed values of $\mathrm{CHD}<3 \mathrm{~mm}$ and $\mathrm{CA}$ $<2^{\circ}$, corroborating with the literature regarding the idea that non-structured HTCs do not require instrumentation. Suh et al. evaluated 89 patients, identifying the factors that cause imbalance in the shoulder after surgical treatment, and concluded that proximal thoracic curves with Cobb angle $<25^{\circ}$ in tilt radiographs do not need to be instrumented. ${ }^{12}$

It is also worth reiterating our observation about the risks of patients with $\mathrm{CHD}>3 \mathrm{~mm}$ and $\mathrm{CA}>2^{\circ}$ one year following surgery, which were similar between the examinations with a low Cobb value and a high Cobb value in non-structured proximal thoracic curves.

In view of the above, the protocol in our service is to evaluate the sagittal plane in all patients pre- and postoperatively, given that, after one year of follow-up, in $96.7 \%$ of the patients we achieved the ideal mismatch, demonstrating a good surgical outcome.

\section{CONCLUSION}

In this study we observed that when the proximal thoracic curve is not structured, even with an elevated Cobb angle, instrumentation is not needed to achieve satisfactory postoperative shoulder alignment. Therefore, our study corroborates the Lenke classification, demonstrating that instrumentation of the non-structured proximal curve is not necessary.

All authors declare no potential conflict of interest related to this article. 
CONTRIBUTION OF THE AUTHORS: Each author made significant individual contributions to this manuscript. CMM (0000-0001-6670-5159* and RSL (0000-0002-3164-420X)* were the main contributors to the writing of the article. CMM, RSF (0000-0001-9666-0377)*, and RSL performed the surgical procedures and gathered the clinical data. CMM, RSL and RESJ (0000-0003-4909-168X)* evaluated the statistical analysis data. CMM, RSL, and RESJ conducted the literature review, reviewed the article, and contributed to the intellectual concept of the study. *ORCID (Open Researcher and Contributor ID).

\section{REFERENCES}

1. Haher TR, Merola A, Zipnick RI, Gorup J, Mannor D, Orchowski J. (1995) Meta-analysis of surgical outcome in adolescent idiopathicscoliosis. A 35-year English literature review of 11,000 patients. Spine (Phila Pa 1976). 1995;20(14):1575-84.

2. Terheyden $\mathrm{JH}$, Wetterkamp $M$, Gosheger G, Bullmann $V$, Lijenqvist $U$, Lange $T$, et al. Predictors of shoulder level after spinal fusion in adolescente idiopathic scoliosis. Eur Spine J. 2016;27(2):370-80.

3. Qiu XS, Ma WW, Li WG, Wang B, Yu Y, Zhu ZZ, et al. Discrepancy between radiographic shoulder balance and cosmetic shoulder balance in adolescent idiopathic scoliosis patients with double thoracic curve. Eur Spine J. 2009;18(1):45-51.

4. Andújar ALF, Rocha LEMR, Menezes CM. Surgical Techniques for Adolescent Idiopathic Scoliosis and the Selection of Fusion Levels. Aospine master series. 2017.

5. Zheng CK, Kan WS, Li P, Zhao ZG, Li K. Treatment for severe idiopathic upper thoracic scoliosis in adolescence. J Spinal Disord Tech. 2013;26(2):107-11.

6. Hong JY, Suh SW, Yang JH, Park SY, Han JH. Reliability Analysis of Shoulder Balance Measures. Spine (Phila Pa 1976). 2013;38(26):E1684-90.

7. Asher M, Min Lai S, Burton D, Manna B. The reliability and concurrent validity of the Scoliosis Research Society-22 patient questionnaire for idiopathic scoliosis. Spine (Phila Pa 1976). 2003;28(1):63-9.
8. Smith PL, Donaldson S, Hedden D, Alman B, Howard A, Stephens D, et al. Parents' and patients' perceptions of postoperative appearance in adolescent idiopathic scoliosis. Spine (Phila Pa 1976). 2006;31(20):2367-74.

9. Hong JY, Suh SW, Modi HN, Hur CY, Song HR, Park JH. Reliability analysis for radiographic measures of lumbar lordosis in adult scoliosis: a casecontrol study comparing 6 methods. Eur Spine J. 2010;19(9):1551-7.

10. Hwang JH, Modi HN, Suh SW, Hong JY, Park YH, Park JH, et al. Reliability of lumbar lordosis measurement in patients with spondylolisthesis: a case-control study comparing the Cobb, centroid, and posterior tangent methods. Spine (Phila Pa 1976). 2010;35(18):1691-700.

11. Lenke LG, Betz RR, Harms J, Bridwell KH, Clements DH, Lowe TG, et al. Adolescent idiopathic scoliosis: a new classification to determine extent of spinal arthrodesis. J Bone Joint Surg Am. 2001;83-A(8):1169-81.

12. Hong JY, Suh SW, Modi HM, Yang JH, Park SY. Analysis of factors that affect shoulder balance after correction surgery in scoliosis: a global analysis of all the curvature types. Eur Spine J. 2013;22(6):1273-85. 